\section{Kidney \\ Blood Pressure Research}

\title{
Effect of Carbon Monoxide Donor CORM-2 on Vitamin $\mathrm{D}_{3}$ Metabolism
}

\author{
Martina Feger ${ }^{a, f} \quad$ Abul Fajola ${ }^{a, f} \quad$ Aleksandra Lebedeva ${ }^{a, b} \quad$ Adrian Meissner $^{a}$ \\ Diana Michael $^{a} \quad$ Jakob Voelkl $^{\mathrm{a}} \quad$ Ioana Alesutan $^{\mathrm{a}}$ Erwin Schleicher ${ }^{\mathrm{c}}$ \\ Christoph Reichetzeder ${ }^{d} \quad$ Berthold Hocher $^{d} \quad$ Syed M. Qadria,e,g Florian Langa,g
}

aDepartment of Physiology, University of Tübingen, Tübingen, Germany; ${ }^{b}$ Department of Immunology, Institute of Experimental Medicine, St. Petersburg, Russia; 'Department of Internal Medicine, University of Tübingen, Tübingen, Germany; 'Institute of Nutritional Science, University of Potsdam, Potsdam, Germany, e'Department of Pharmacology, University of Saskatchewan, Saskatoon, Canada; ${ }^{{ }^{C}}$ contributed equally and thus share first authorship; ${ }^{9} \mathrm{Contributed} \mathrm{equally} \mathrm{and} \mathrm{thus} \mathrm{share} \mathrm{last} \mathrm{authorship}$

Key Words

CORM-2 • 1,25-Dihydroxyvitamin $\mathrm{D}_{3} \cdot$ Klotho $•$ FGF23 $•$ Phosphate $\cdot$ Calcium

\begin{abstract}
Background/Aims: Carbon monoxide (CO) interferes with cytochrome-dependent cellular functions and acts as gaseous transmitter. $\mathrm{CO}$ is released from $\mathrm{CO}$-releasing molecules (CORM) including tricarbonyl-dichlororuthenium (II) dimer (CORM-2), molecules considered for the treatment of several disorders including vascular dysfunction, inflammation, tissue ischemia and organ rejection. Cytochrome P450-sensitive function include formation of 1,25-dihydroxyvitamin $\mathrm{D}_{3}\left(1,25(\mathrm{OH})_{2} \mathrm{D}_{3}\right)$ by renal 25 -hydroxyvitamin $\mathrm{D}_{3} 1$-alpha-hydroxylase (Cyp27b1). The enzyme is regulated by PTH, FGF23 and klotho. $1,25(\mathrm{OH})_{2} \mathrm{D}_{3}$ regulates $\mathrm{Ca}^{2+}$ and phosphate transport as well as klotho expression. The present study explored, whether CORM2 influences $1,25(\mathrm{OH})_{2} \mathrm{D}_{3}$ formation and klotho expression. Methods: Mice were treated with intravenous CORM-2 (20 mg/kg body weight). Plasma $1,25(\mathrm{OH})_{2} \mathrm{D}_{3}$ and FGF23 concentrations were determined by ELISA, phosphate, calcium and creatinine concentrations by colorimetric methods, transcript levels by quantitative RT-PCR and protein expression by western blotting. Fgf23 mRNA transcript levels were further determined in rat osteosarcoma UMR106 cells without or with prior treatment for 24 hours with $20 \mu \mathrm{M}$ CORM-2. Results: CORM-2 injection within 24 hours significantly increased FGF23 plasma levels and decreased $1,25(\mathrm{OH})_{2} \mathrm{D}_{3}$ plasma levels, renal Cyp27b1 gene expression as well as renal klotho protein abundance and transcript levels. Moreover, treatment of UMR106 cells with CORM-2 significantly increased Fgf23 transcript levels. Conclusion: CO-releasing molecule CORM-2 enhances FGF23 expression and release and decreases klotho expression and $1,25(\mathrm{OH})_{2} \mathrm{D}_{3}$ synthesis.
\end{abstract}

Copyright (C) 2013 S. Karger AG, Basel

Prof. Dr. Florian Lang
Physiologisches Institut der Universität Tübingen, Gmelinstr. 5, D-72076 Tuebingen (Germany), Tel. +49 707129 72194, Fax +49 7071295618

E-Mail florian.lang@uni-tuebingen.de 


\section{Kidney Blood Pressure Research}

Feger et al.: CORM-2-induced inhibition of vitamin D3 activation

\section{Introduction}

Carbon monoxide ( $\mathrm{CO}$ ), a gas, which is highly toxic to humans and animals when encountered in higher concentrations, binds rapidly to hemoglobin (Hb), leading to the stable formation of carboxyhemoglobin ( $\mathrm{COHb}$ ) [1]. As a result of $\mathrm{CO}$ binding to $\mathrm{Hb}$ both $\mathrm{O}_{2}$ binding at high and $\mathrm{O}_{2}$ release at low $\mathrm{O}_{2}$ partial pressure are impaired [1] leading to a reduced oxygen carrying capacity of blood after $\mathrm{CO}$ inhalation [2].

Besides its toxic effects at high concentrations, $\mathrm{CO}$ is a gaseous transmitter molecule [3]. In mammalian cells $\mathrm{CO}$ is generated by the enzyme heme-oxygenase [4]. CO participates in the regulation of a wide variety of cellular functions [5-9] and contributes to the regulation of cell death [10-15]. CO may elicit both vasodilation and vasoconstriction [16,17]. In addition, CO fosters coagulation and attenuates fibrinolysis in vitro and in vivo $[18,19]$. CO can be released in an organism by the tricarbonyl-dichlororuthenium (II) dimer (CORM-2) [6]. CO-releasing molecules have been suggested as therapeutic option in various pathologies, but the risks of treatment with those molecules have been insufficiently addressed [6, 20].

$\mathrm{CO}$ interferes with the function of cytochromes [21-23]. The cytochrome P450 enzyme 25-hydroxyvitamin $\mathrm{D}_{3}$ 1-alpha-hydroxylase accomplishes formation of 1,25-dihydroxyvitamin $\mathrm{D}_{3}\left(1,25(\mathrm{OH})_{2} \mathrm{D}_{3}\right)$ from its inactive precursor (25-hydroxyvitamin $\mathrm{D}_{3}$ ) [24]. The enzyme 25-hydroxyvitamin $D_{3} 1$-alpha-hydroxylase is encoded by the Cyp27b1 gene [24]. $1,25(\mathrm{OH})_{2} \mathrm{D}_{3}$ is inactivated by 1,25 -dihydroxyvitamin $\mathrm{D}_{3} 24$-hydroxylase, an enzyme encoded by the Cyp24a1 gene [25]. 1,25(OH) ${ }_{2} \mathrm{D}_{3}$ is a powerful regulator of $\mathrm{CaHPO}_{4}$ metabolism and lack of $1,25(\mathrm{OH})_{2} \mathrm{D}_{3}$ leads to rickets and osteomalacia [26]. Reduced levels of $1,25(\mathrm{OH})_{2} \mathrm{D}_{3}$ are further associated with the onset and progression of various diseases such as respiratory infections, cardiovascular disease and cancer [27-30]. 1,25(OH) $)_{2} \mathrm{D}_{3}$ formation is inhibited by joint action of klotho and FGF23, proteins regulating phosphate homeostasis and implicated in various disorders including arteriosclerosis, cancer metastasis, and chronic kidney disease [31-33]. Furthermore, heme-oxygenase- 1 is involved in bone metabolism and inflammation [34, 35].

The present study explored, whether the $\mathrm{CO}$ donor tricarbonyl-dichlororuthenium (II) dimer (CORM-2) influences vitamin $\mathrm{D}_{3}$ metabolism $[6,14]$. To this end, vitamin D metabolism was investigated after CORM-2 injection into mice.

\section{Materials and Methods}

All animal experiments were conducted according to the German law for the welfare of animals and were approved by local authorities. Male and female BALB/c mice had free access to food (ssniff Spezialdiäten, Soest, Germany) containing $7000 \mathrm{mg} / \mathrm{kg}$ phosphorus and to tap drinking water ad libitum. Where indicated, the CO-releasing molecule tricarbonyldichlororuthenium (II) dimer (CORM-2, Sigma Aldrich, Taufkirchen, Germany), solubilized in dimethyl sulfoxide (DMSO, Sigma Aldrich), was injected intravenously (20 mg/kg body weight). Control mice were injected with vehicle (10\% DMSO in saline solution).

To determine excretion of phosphate, the mice were placed individually in metabolic cages (Techniplast, Hohenpeissenberg, Germany) for 24-hour urine collection [36, 37]. They were allowed a 2-day habituation period. Subsequently, 24-hour collection of urine was performed. To assure quantitative urine collection, metabolic cages were siliconized, and urine was collected under water-saturated oil [38]. The urinary phosphate concentration was determined colorimetrically utilizing a commercial diagnostic kit (Roche Diagnostics, Mannheim, Germany) [39].

To obtain blood specimens, mice were lightly anaesthetized with isoflurane (Abott, WiesbadenDelkenheim, Germany) and about 50 - $200 \mu$ of blood was withdrawn into heparinized capillaries by puncturing the retro-orbital plexus [40]. The plasma concentrations of phosphate and $\mathrm{Ca}^{2+}$ were measured by a photometric method (FUJI FDC 3500i, Sysmex, Norsted, Germany). The creatinine concentrations in plasma were measured using a commercial enzymatic kit (creatinine PAP, Labor \& Technik, Berlin, Germany, based on the creatininase method). An EIA kit was employed to determine plasma concentrations of $1,25(\mathrm{OH})_{2} \mathrm{D}_{3}$ (IDS, Boldon, UK). Plasma FGF23 (C-Term) concentrations were determined utilizing a commercial ELISA Kit (Immutopics, San Clemente, USA) [41]. 


\section{Kidney \\ Blood Pressure Research}

After 24 hours of CORM-2 treatment, mice were anesthetized with isoflurane and sacrificed by cervical dislocation. The kidneys were removed and immediately snap frozen in liquid nitrogen [42]. To determine protein expression by western blotting, kidneys were lysed with ice-cold lysis buffer (54.6 mM HEPES; 2.69 mM Na4P207; 360 mM NaCl; 10\% [vol/vol] Glycerol; 1\% [vol/vol] NP40) containing phosphatase and protease inhibitors (Complete mini, Roche, Mannheim, Germany). Homogenates were clarified by centrifugation at $12000 \mathrm{rpm}$ for $20 \mathrm{~min}$ [43]. Total protein was separated by SDS-PAGE (8\% Tris-Glycine), transferred to nitrocellulose membranes (Schleicher and Schuell, Dassel, Germany), blocked for $1 \mathrm{~h}$ in blocking buffer (5\% fat-free milk in Tris-buffered saline (TBS) containing 0.1\% Tween (TBST)),and incubated overnight with an anti-klotho antibody (1:1000 in 5\% fat-free milk in TBS-T, KM2076 (Rat), kindly provided by Kyowa Hakko Kirin Co. Ltd, Japan). After incubation with an anti-rat secondary antibody (1:2000 in 5\% fat-free milk in TBS-T, Cell Signaling), the bands were visualized with enhanced chemiluminescence according to the manufacturer's instructions. Homogenates were also probed with a primary Gapdh antibody (1:2000 in 5\% BSA in TBS-T, Cell Signaling) as a loading control. Densitometric analysis of klotho and Gapdh was performed using Quantity One software (Bio-Rad Laboratories, München, Germany).

Rat osteosarcoma UMR106 cells were routinely cultured in Dulbecco's Modified Eagle Medium (DMEM) containing 4,5 g/l glucose (PAA Laboratories, Cölbe, Germany), supplemented with 2 mM L-glutamine (PAA Laboratories, Cölbe, Germany), 10\% fetal bovine serum FBS (Gibco, Life Technologies, Darmstadt, Germany), $100 \mathrm{U} / \mathrm{ml}$ penicillin and $100 \mu \mathrm{g} / \mathrm{ml}$ streptomycin (Gibco, Life Technologies, Darmstadt, Germany). Cells were treated for 24 hours with $20 \mu \mathrm{M}$ CORM-2 (Sigma-Aldrich, Taufkirchen, Germany) dissolved in DMSO (Sigma-Aldrich, Taufkirchen, Germany). Equal amounts of vehicle were used as control.

Total RNA was isolated from kidney samples and from UMR106 cells by using Trifast Reagent (Peqlab, Erlangen, Germany) according to the manufacturer's instructions [44]. Reverse transcription of $2 \mu \mathrm{g}$ RNA was performed using oligo(dT) $)_{12-18}$ primers (Invitrogen, Darmstadt, Germany) and SuperScriptIII Reverse Transcriptase (Invitrogen, Darmstadt, Germany). cDNA samples were treated with RNaseH (Invitrogen, Darmstadt, Germany). Quantitative real-time PCR was performed with the iCycler iQ ${ }^{\mathrm{TM}}$ Real-Time PCR Detection System (Bio-Rad Laboratories, München, Germany) and iQ $^{\mathrm{TM}}$ Sybr Green Supermix (Bio-Rad Laboratories, München, Germany) according to the manufacturer's instructions. The following mouse primers were used ( $5^{\prime} \rightarrow 3^{\prime}$ orientation) for quantitative RT-PCR measurements:

Cyp24a1 fw: GTGAAGCGTGCGCCAAAAG; Cyp24a1 rev: CTCACCGTCGGTCATCAGC;

Cyp27b1 fw: CAGTTTACGTTGCCGACCCTA; Cyp27b1 rev: GGACAGTGACTTTCTTGTCGC;

Gapdh fw: AGGTCGGTGTGAACGGATTTG; Gapdh rev: TGTAGACCATGTAGTTGAGGTCA;

Klotho fw: CCCTGTGACTTTGCTTGGG; Klotho rev: CCCACAGATAGACATTCGGGT.

The following rat primers were used $\left(5^{\prime} \rightarrow 3^{\prime}\right.$ orientation) for quantitative RT-PCR measurements:

Fgf23 fw: TTGGATCGTATCACTTCAGC; Fgf23 rev: TGCTTCGGTGACAGGTAG;

Gapdh fw: GGCAAGTTCAATGGCACAGT; Gapdh rev: TGGTGAAGACGCCAGTAGACTC.

The specificity of the PCR products was confirmed by analysis of the melting curves and in addition by agarose gel electrophoresis. All PCRs were performed in duplicate, and mRNA fold changes were calculated by the $2^{-\Delta \Delta \mathrm{Ct}}$ method using Gapdh as internal reference.

Data are expressed as arithmetic means \pm SEM, and $n$ represents the number of independent experiments. Statistical analysis was made using unpaired Student $t$-test or Mann-Whitney test. Only differences with $\mathrm{p}<0.05$ were considered statistically significant.

\section{Results}

To investigate the effects of the tricarbonyl-dichlororuthenium (II) dimer (CORM-2) on vitamin D metabolism, the CO-releasing molecule CORM-2 was administered to mice by intravenous injection. For comparison, equal amounts of DMSO vehicle was injected into control mice. CORM-2 releases a controlled amount of CO in biological systems [6]. CORM2 treatment of mice for 24 hours led to a statistically significant decrease of plasma 1,25-dihydroxyvitamin $\mathrm{D}_{3}\left(1,25(\mathrm{OH})_{2} \mathrm{D}_{3}\right)$ concentration as compared to the control treated mice (Fig. 1). The decrease of plasma $1,25(\mathrm{OH})_{2} \mathrm{D}_{3}$ concentrations following CORM-2 


\section{Kidney \\ Blood Pressure \\ Research}

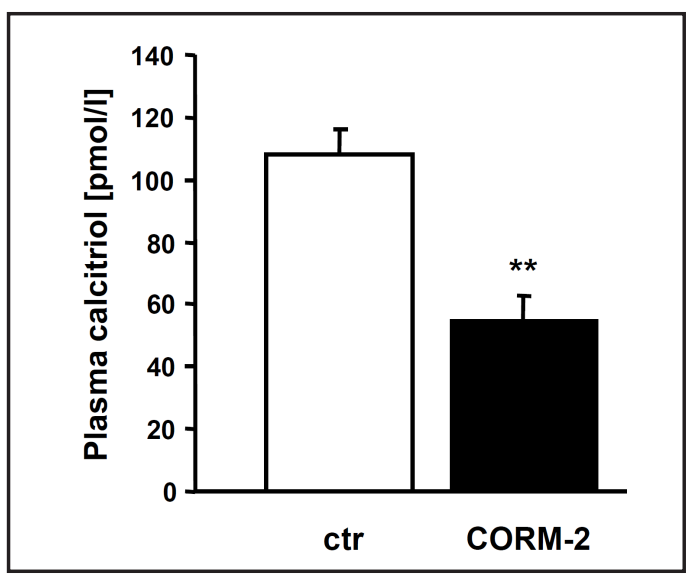

Fig. 1. Arithmetic means \pm SEM $(n=8)$ of plasma calcitriol concentration (pmol/l) in mice 24 hours after the injection of vehicle control (ctr, white bar) or the injection of $20 \mathrm{mg} / \mathrm{kg}$ body weight CORM-2 (CORM-2, black bar). ${ }^{* *}(\mathrm{p}<0.01)$ indicates statistically significant difference from vehicle treated mice.

Fig. 2. Arithmetic means \pm SEM ( $\mathrm{n}=7-8)$ of Cyp27b1 $\square$ (A) and Cyp24a1 (B) mRNA expression (arbitrary units) in kidney tissues from mice 24 hours after the injection of vehicle control (ctr, white bars) or the injection of $20 \mathrm{mg} / \mathrm{kg}$ body weight CORM-2 (CORM-2, black bars). ${ }^{* * *}(\mathrm{p}<0.001)$ indicates statistically significant difference from vehicle treated mice.

treatment was accompanied by a statistically significant decrease of renal transcript levels of Cyp27b1, the gene encoding 25-hydroxyvitamin $\mathrm{D}_{3} 1$-alpha-hydroxylase, a cytochrome P450dependent enzyme producing $1,25(\mathrm{OH})_{2} \mathrm{D}_{3}$ (Fig.2A). Transcript levels of Cyp24a1 encoding the $1,25(\mathrm{OH})_{2} \mathrm{D}_{3}$ inactivating 1,25-dihydroxyvitamin $\mathrm{D}_{3}$ 24-hydroxylase tended to increase following CORM-2 treatment, an effect, however, not reaching statistical significance (Fig. 2B). Despite reduced $1,25(\mathrm{OH})_{2} \mathrm{D}_{3}$ levels, no significant difference was observed in the plasma $\mathrm{Ca}^{2+}$ concentrations between the control treated mice $(8.90 \pm 0.17 \mathrm{mg} / \mathrm{dl}, \mathrm{n}=12)$ and CORM2 treated mice $(9.09 \pm 0.13 \mathrm{mg} / \mathrm{dl}, \mathrm{n}=12)$. Similarly, plasma phosphate concentrations were not significantly different between control treated mice $(6.75 \pm 0.36 \mathrm{mg} / \mathrm{dl}, \mathrm{n}=12)$ and CORM2 treated mice $(6.76 \pm 0.37 \mathrm{mg} / \mathrm{dl}, \mathrm{n}=12)$. Furthermore, the urinary phosphate excretion was not significantly different between control treated mice $(2.34 \pm 0.36 \mu \mathrm{mol} / 24 \mathrm{~h} /[\mathrm{g}] \mathrm{BW}$, $\mathrm{n}=12)$ and CORM-2 treated mice $(2.65 \pm 0.42 \mu \mathrm{mol} / 24 \mathrm{~h} /[\mathrm{g}] \mathrm{BW}, \mathrm{n}=12)$. In addition, 12 hours after the injection of CORM-2, plasma creatinine concentrations were not significantly different between CORM- 2 treated mice $(0.383 \pm 0.040 \mathrm{mg} / \mathrm{dl}, \mathrm{n}=5)$ and control treated mice $(0.300 \pm 0.038 \mathrm{mg} / \mathrm{dl}, \mathrm{n}=5)$.

CORM-2 injection was, however, followed by an increase of plasma FGF23 concentration. As shown in Fig. 3A, the plasma FGF23 (C-Term) levels were significantly higher in mice receiving CORM-2 treatment than in control treated mice. To investigate, whether CORM-2 could directly affect FGF23 production, rat osteosarcoma UMR106 cells were treated for 24 hours with DMSO as control or with $20 \mu \mathrm{M}$ CORM-2 (Fig. 3B). As a result, CORM-2 induced a statistically significant increase in Fgf23 mRNA expression in UMR106 cells as compared to the vehicle treated UMR106 cells.

Renal Klotho mRNA levels determined by quantitative RT-PCR, were significantly lower in mice following CORM-2 treatment than in control treated mice (Fig. 4A). According to 


\section{Kidney \\ Blood Pressure \\ Research}

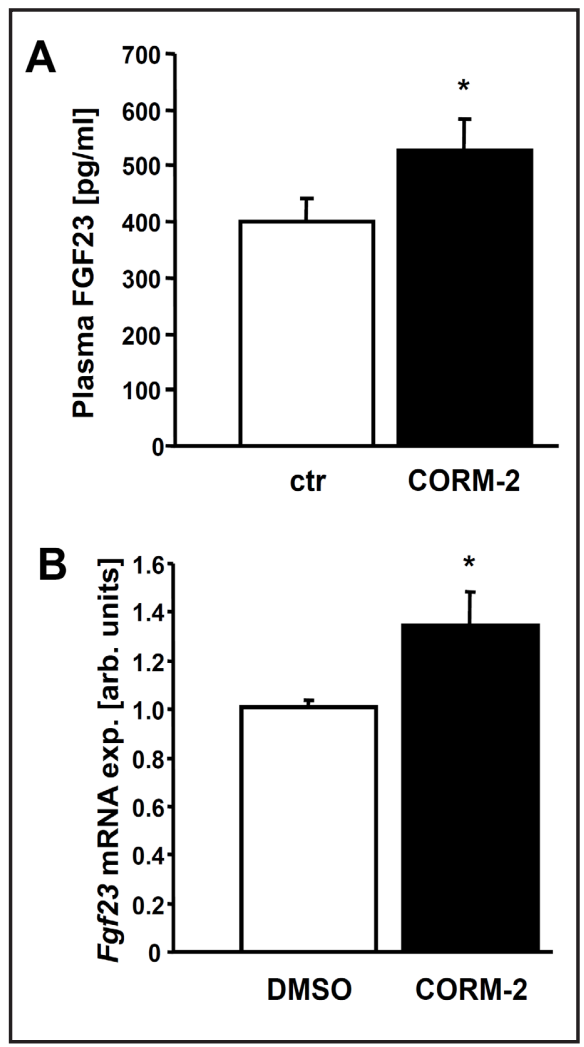

Fig. 3. (A) Arithmetic means \pm SEM ( $n=$ 12) of plasma FGF23 (C-Term) concentration $(\mathrm{pg} / \mathrm{ml})$ in mice 24 hours after the injection of vehicle control (ctr, white bar) or the injection of $20 \mathrm{mg} / \mathrm{kg}$ body weight CORM-2 (CORM-2, black bar). ${ }^{*}(\mathrm{p}<0.05)$ indicates statistically significant difference from vehicle treated mice. (B) Arithmetic means \pm SEM ( $n=10$; arbitrary units) of Fgf23 mRNA expression in UMR106 cells following a 24 hours treatment with vehicle alone (ctr; white bar) or with $20 \mu \mathrm{M}$ CORM-2 (CORM-2, black bar). * $\left.{ }^{*} \mathrm{p}<0.05\right)$ indicates statistically significant difference from UMR106 cells treated with vehicle alone.

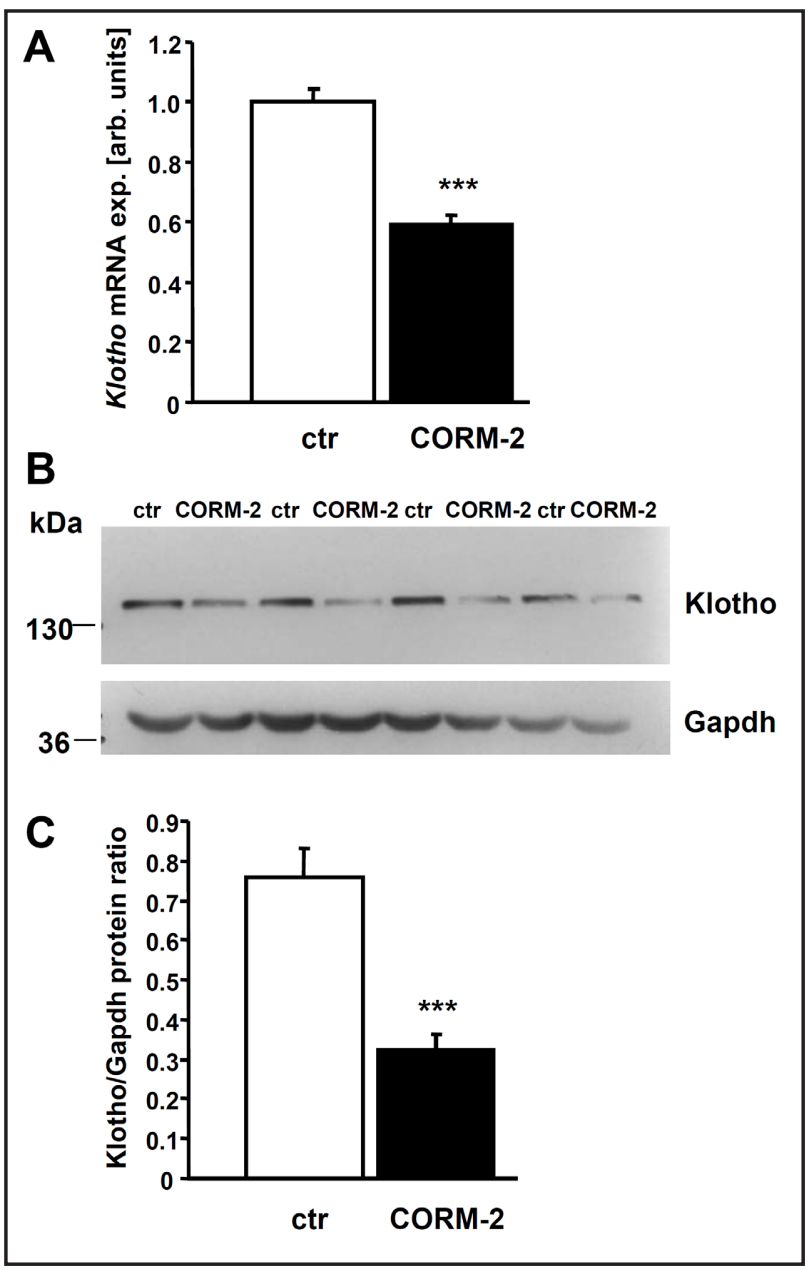

Fig. 4. (A) Arithmetic means \pm SEM ( $n=7-8$ ) of Klotho mRNA expression (arbitrary units) in kidney tissues from mice 24 hours after the injection of vehicle control (ctr, white bar) or the injection of $20 \mathrm{mg} / \mathrm{kg}$ body weight CORM-2 (CORM-2, black bar). (B) Representative original western blots showing Klotho/Gapdh protein abundance in kidney tissues from mice following the injection of vehicle control (ctr) or the injection of $20 \mathrm{mg} / \mathrm{kg}$ body weight CORM-2 (CORM-2). (C) Arithmetic means \pm SEM $(n=7)$ of Klotho/Gapdh protein ratio in kidney tissues from mice 24 hours after the injection of vehicle control (ctr, white bar) or the injection of $20 \mathrm{mg} / \mathrm{kg}$ body weight CORM-2 (CORM-2, black bar). ${ }^{* * *}(\mathrm{p}<0.001)$ indicates statistically significant difference from vehicle treated mice.

western blotting, the renal abundance of klotho protein was again significantly lower in CORM-2 treated mice than in control treated mice (Fig. 4B,C).

\section{Discussion}

The present study discloses that the CO donor tricarbonyl-dichlororuthenium (II) dimer (CORM-2) decreases renal transcript levels of Cyp27b1, the gene encoding the 1,25-dihydroxyvitamin $\mathrm{D}_{3} \quad\left(1,25(\mathrm{OH})_{2} \mathrm{D}_{3}\right)$-generating 25 -hydroxyvitamin $\mathrm{D}_{3} \quad 1$-alpha- 


\section{Kidney Blood Pressure Research}

\begin{tabular}{l|l}
\hline Kidney Blood Press Res 2013;37:496-505 \\
\hline DOI: $10.1159 / 000355730$ & (c) 2013 S. Karger AG, Basel
\end{tabular}

Publisned online: November 11, 2013

www.karger.com/kbr

Feger et al.: CORM-2-induced inhibition of vitamin D3 activation

hydroxylase. Accordingly, CORM-2 decreases the plasma $1,25(\mathrm{OH})_{2} \mathrm{D}_{3}$ level. The observations further reveal that CORM-2 decreases renal klotho expression, increases plasma FGF23 levels and enhances FGF23 expression in rat osteosarcoma UMR106 cells.

FGF23 is mainly produced and released by osteoblasts/osteocytes [45]. The upregulation of FGF23 plasma levels and mRNA expression in UMR106 cells may thus point to a direct effect of CORM-2 on FGF23 release from bone. We cannot rule out effects of CORM-2 indirectly modifying FGF23 release. As FGF23 release is stimulated by $1,25(\mathrm{OH})_{2} \mathrm{D}_{3}$ [45], the upregulation of FGF23 release cannot be explained by the decline of $1,25(\mathrm{OH})_{2} \mathrm{D}_{3}$ plasma levels. As FGF23 downregulates 1-alpha-hydroxylase [45], the increased FGF23 plama levels could, however, contribute to or even account for the decreased $1,25(\mathrm{OH})_{2} \mathrm{D}_{3}$ formation following CORM-2 treatment. FGF23 modifies $1,25(\mathrm{OH})_{2} \mathrm{D}_{3}$ plasma levels by inhibiting formation rather than stimulating $1,25(\mathrm{OH})_{2} \mathrm{D}_{3}$ degradation [46]. The inhibitory effect on $1,25(\mathrm{OH})_{2} \mathrm{D}_{3}$ formation could further be due to down-regulation of Cyp27b1 (Fig. 2) and/or binding of CO to cytochrome $\mathrm{P} 450$ with subsequent impairment of 25-hydroxyvitamin $\mathrm{D}_{3} 1$-alpha-hydroxylase activity [24]. The downregulation of klotho would, however, be expected to attenuate the effect of FGF23 on 25-hydroxyvitamin $\mathrm{D}_{3} 1$-alpha-hydroxylase activity [45, 47].

CO increases cellular oxygen consumption, reduces mitochondrial respiratory capacity and increases VEGF production via HIF-1 $\alpha$, which could possibly contribute to the regulation of FGF23 by CORM-2 [48, 49]. Along those lines production of FGF23, Cyp24a1 and Cyp27b1 expression as well as $1,25(\mathrm{OH})_{2}$ vitamin $\mathrm{D}_{3}$ plasma levels are modified by iron deficiency, an effect associated with tissue hypoxia [50, 51].

As $1,25(\mathrm{OH})_{2} \mathrm{D}_{3}$ stimulates the expression of klotho [45], the decrease of $1,25(\mathrm{OH})_{2} \mathrm{D}_{3}$ formation could contribute to or even account for the decrease of klotho expression following CORM-2 treatment. The regulation of Klotho mRNA expression is vitamin $\mathrm{D}_{3}$ receptormediated, and vitamin $\mathrm{D}_{3}$ response elements (VDREs) in both mouse and human klotho genes have been identified [52]. Beyond that, a direct toxic effect of the ruthenium based carrier molecule of CORM-2 on the kidney cannot be ruled out [20]. CORM-2 did, however, not significantly affect plasma creatinine, calcium and phosphate concentrations or urinary phosphate excretion.

The influence of CORM-2 described here may contribute to the known effects of CORM-2. Several vasculoprotective effects of lower dosages of CORM-2 have been described and low dosages of $\mathrm{CO}$ are associated with nephroprotection [53]. However, increased endogenous carbon monoxide production may be involved in diabetes induced endothelial dysfunction [54]. Similarly, klotho is decreased in the $\mathrm{db} / \mathrm{db}$, streptozotocin diabetes models and human diabetic nephropathy [55-57]. Heme oxygenase derived endogenous CO promotes endothelial dysfunction in hypertensive rats, and high levels of CO could impair nitric oxide release [58]. Blockage of the nitric oxide synthase also leads to reduced klotho expression [59].

Biological effects of $1,25(\mathrm{OH})_{2} \mathrm{D}_{3}$ are mainly mediated by activation of the vitamin $\mathrm{D}_{3}$ receptor (VDR) [60, 61]. Low 1,25-dihydroxyvitamin $\mathrm{D}_{3}$ levels may lead to demineralization of bone [26] and in addition play a role in the development and progression of multiple chronic diseases such as cancer, infections, and cardiovascular disorders [27-30].

The present observations may hint at effects of smoking, which leads to massive formation of $\mathrm{CO}[62,63]$. $\mathrm{CO}$ binds rapidly to hemoglobin $(\mathrm{Hb})$, leading to the stable formation of carboxyhemoglobin (COHb) [2]. Similar to $1,25(\mathrm{OH})_{2} \mathrm{D}_{3}$ formation after CORM-2 treatment, smoking is associated with reduced vitamin $\mathrm{D}_{3}$ levels without changes in serum calcium [64]. Furthermore, history of tobacco smoking is associated with elevated FGF23 levels in CKD patients [65]. Tobacco smoke plays a decisive role in the pathogenesis of lung cancer [66], chronic obstructive pulmonary disease (COPD) [66] and cardiovascular disease [67]. The underlying mechanisms are incompletely understood [68], but may, at least in theory, involve altered action of $1,25(\mathrm{OH})_{2} \mathrm{D}_{3}$, klotho or FGF23. Both, COPD and smoking, are associated with an increased carbon monoxide load and risk of vitamin $\mathrm{D}_{3}$ deficiency $[69,70] .1,25(\mathrm{OH})_{2} \mathrm{D}_{3}$ may be a potent regulator of several signaling pathways, which are involved in oncogenic transformation $[25,61,71]$. Secreted klotho functions as a humoral factor and regulates the 


\section{Kidney \\ Blood Pressure Research}

activity of multiple growth factors, including insulin/insulin-like growth factor-1 (IGF-1) [72], Wnt [73], and TGF-ß1 [74]. Soluble klotho has been identified as a potent inhibitor of the insulin/IGF-1 pathways in cancer cells $[75,76]$. Klotho inhibits lung cancer cell growth and klotho expression is a predictor of a favourable outcome in lung cancer patients [77, $78]$. Future studies will be required to define the role of decreased $1,25(\mathrm{OH})_{2} \mathrm{D}_{3}$ and klotho formation in the untoward effects of $\mathrm{CO}$.

\section{Conclusion}

CORM-2 leads to a decrease of 25-hydroxyvitamin $\mathrm{D}_{3}$ 1-alpha-hydroxylase expression and activity resulting in decreased formation of $1,25(\mathrm{OH})_{2} \mathrm{D}_{3}$ and klotho expression. Moreover, CORM-2 increases the formation of FGF23. The observations disclose an impact of CO-releasing molecules on mineral metabolism.

\section{Acknowledgements}

The authors acknowledge the meticulous preparation of the manuscript by Lejla Subasic and Tanja Loch. The Klotho antibody was a kind gift from Kyowa Hakko Kirin Co.Ltd, Japan. The study was supported by the DFG and the Open Access Publishing Fund of Tuebingen University.

\section{References}

1 Haab P: The effect of carbon monoxide on respiration. Experientia 1990;46:1202-1206.

-2 Prockop LD, Chichkova RI: Carbon monoxide intoxication: an updated review. J Neurol Sci 2007;262:122130.

- Gullotta F, di Masi A, Coletta M, Ascenzi P: CO metabolism, sensing, and signaling. Biofactors 2012;38:1-13.

$\checkmark 4$ Toyama T, Shinkai Y, Sumi D, Kumagai Y: Carbon monoxide derived from heme oxygenase-2 mediates reduction of methylmercury toxicity in SH-SY5Y cells. Toxicol Appl Pharmacol 2010;249:86-90.

-5 Loennechen JP, Nilsen OG, Arbo I, Aadahl P, Nilsen T, Waldum HL, Sandvik AK, Ellingsen O: Chronic exposure to carbon monoxide and nicotine: endothelin ET(A) receptor antagonism attenuates carbon monoxide-induced myocardial hypertrophy in rat. Toxicol Appl Pharmacol 2002;178:8-14.

6 Motterlini R, Mann BE, Foresti R: Therapeutic applications of carbon monoxide-releasing molecules. Expert Opin Invest Drugs 2005;14:1305-1318.

7 Rao D, Fechter LD: Protective effects of phenyl-N-tert-butylnitrone on the potentiation of noise-induced hearing loss by carbon monoxide. Toxicol Appl Pharmacol 2000;167:125-131.

8 Thom SR, Ohnishi ST, Fisher D, Xu YA, Ischiropoulos H: Pulmonary vascular stress from carbon monoxide. Toxicol Appl Pharmacol 1999;154:12-19.

-9 Thom SR, Fisher D, Zhang J, Bhopale VM, Cameron B, Buerk DG: Neuronal nitric oxide synthase and $\mathrm{N}$-methyl-D-aspartate neurons in experimental carbon monoxide poisoning. Toxicol Appl Pharmacol 2004;194:280-295.

10 Ahanger AA, Prawez S, Kumar D, Prasad R, Amarpal, Tandan SK: Wound healing activity of carbon monoxide liberated from CO-releasing molecule (CO-RM). Naunyn Schmiedebergs Arch Pharmacol 2011;384:93-102.

11 Kim YM, Choi BM, Kim YS, Kwon YG, Kibbe MR, Billiar TR, Tzeng E: Protective effect of p53 in vascular smooth muscle cells against nitric oxide-induced apoptosis is mediated by up-regulation of heme oxygenase-2. BMB Rep 2008;41:164-169.

-12 Li MH, Cha YN, Surh YJ: Carbon monoxide protects PC12 cells from peroxynitrite-induced apoptotic death by preventing the depolarization of mitochondrial transmembrane potential. Biochem Biophys Res Commun 2006;342:984-990. 


\section{Kidney \\ Blood Pressure Research}

Feger et al.: CORM-2-induced inhibition of vitamin D3 activation

13 Soni H, Patel P, Rath AC, Jain M, Mehta AA: Cardioprotective effect with carbon monoxide releasing molecule-2 (CORM-2) in isolated perfused rat heart: Role of coronary endothelium and underlying mechanism. Vascul Pharmacol 2010;68-76.

14 Soni H, Pandya G, Patel P, Acharya A, Jain M, Mehta AA: Beneficial effects of carbon monoxide-releasing molecule-2 (CORM-2) on acute doxorubicin cardiotoxicity in mice: role of oxidative stress and apoptosis. Toxicol Appl Pharmacol 2011;253:70-80.

15 Wei Y, Chen P, de Bruyn M, Zhang W, Bremer E, Helfrich W: Carbon monoxide-releasing molecule-2 (CORM2) attenuates acute hepatic ischemia reperfusion injury in rats. BMC Gastroenterol 2010;10:42.

16 Johnson FK, Johnson RA: Carbon monoxide promotes endothelium-dependent constriction of isolated gracilis muscle arterioles. Am J Physiol Regul Integr Comp Physiol 2003;285:R536-R541.

17 Zhang F, Kaide JI, Rodriguez-Mulero F, Abraham NG, Nasjletti A: Vasoregulatory function of the heme-heme oxygenase-carbon monoxide system. Am J Hypertens 2001;14:62S-67S.

-18 Nielsen VG, Kirklin JK, George JF: Carbon monoxide-releasing molecule-2 decreases fibrinolysis in human plasma. Blood Coagul Fibrinolysis 2009;20:448-455.

19 Nielsen VG, Kirklin JK, George JF: Carbon monoxide releasing molecule-2 increases the velocity of thrombus growth and strength in human plasma. Blood Coagul Fibrinolysis 2009;20:377-380.

20 Winburn IC, Gunatunga K, McKernan RD, Walker RJ, Sammut IA, Harrison JC: Cell damage following carbon monoxide releasing molecule exposure: implications for therapeutic applications. Basic Clin Pharmacol Toxicol 2012;111:31-41.

-21 Kajimura M, Fukuda R, Bateman RM, Yamamoto T, Suematsu M: Interactions of multiple gas-transducing systems: hallmarks and uncertainties of CO, NO, and H2S gas biology. Antioxid Redox Signal 2010;13:157192.

-22 Pun PB, Lu J, Kan EM, Moochhala S: Gases in the mitochondria. Mitochondrion 2010;10:83-93.

-23 Yao P, Hao L, Nussler N, Lehmann A, Song F, Zhao J, Neuhaus P, Liu L, Nussler A: The protective role of HO-1 and its generated products (CO, bilirubin, and Fe) in ethanol-induced human hepatocyte damage. Am J Physiol Gastrointest Liver Physiol 2009;296:G1318-1323.

24 Paulson SK, DeLuca HF: Subcellular location and properties of rat renal 25-hydroxyvitamin D3-1 alphahydroxylase. J Biol Chem 1985;260:11488-11492.

25 Ingraham BA, Bragdon B, Nohe A: Molecular basis of the potential of vitamin D to prevent cancer. Curr Med Res Opin 2008;24:139-149.

26 DeLuca HF: The vitamin D story: a collaborative effort of basic science and clinical medicine. FASEB J 1988;2:224-236.

27 Holick MF, Chen TC: Vitamin D deficiency: a worldwide problem with health consequences. Am J Clin Nutr 2008;87:1080S-1086S.

28 Herr C, Greulich T, Koczulla RA, Meyer S, Zakharkina T, Branscheidt M, Eschmann R, Bals R: The role of vitamin D in pulmonary disease: COPD, asthma, infection, and cancer. Respir Res 2011;12:31.

-29 Tamez H, Thadhani RI: Vitamin D and hypertension: an update and review. Curr Opin Nephrol Hypertens 2012;21:492-499.

30 Vuolo L, Di Somma C, Faggiano A, Colao A: Vitamin D and cancer. Front Endocrinol (Lausanne) 2012;3:58.

-31 Razzaque MS: FGF23, klotho and vitamin D interactions: What have we learned from in vivo mouse genetics studies? Adv Exp Med Biol 2012;728:84-91.

32 Kuro-o M: Endocrine FGFs and Klothos: emerging concepts. Trends Endocrinol Metab 2008;19:239-245.

-33 Kuro-o M, Matsumura Y, Aizawa H, Kawaguchi H, Suga T, Utsugi T, Ohyama Y, Kurabayashi M, Kaname T, Kume E, Iwasaki H, Iida A, Shiraki-Iida T, Nishikawa S, Nagai R, Nabeshima YI: Mutation of the mouse klotho gene leads to a syndrome resembling ageing. Nature 1997;390:45-51.

-34 Alcaraz MJ, Guillen MI, Ferrandiz ML, Megias J, Motterlini R: Carbon monoxide-releasing molecules: a pharmacological expedient to counteract inflammation. Curr Pharm Des 2008;14:465-472.

-35 Lin TH, Tang CH, Hung SY, Liu SH, Lin YM, Fu WM, Yang RS: Upregulation of heme oxygenase-1 inhibits the maturation and mineralization of osteoblasts. J Cell Physiol 2010;222:757-768.

-36 Ackermann TF, Boini KM, Beier N, Scholz W, Fuchss T, Lang F: EMD638683, a novel SGK inhibitor with antihypertensive potency. Cell Physiol Biochem 2011;28:137-146.

-37 Tang C, Zelenak C, Volkl J, Eichenmuller M, Regel I, Frohlich H, Kempe D, Jimenez L, Le Bellego L, Vergne S, Lang F: Hydration-sensitive gene expression in brain. Cell Physiol Biochem 2011;27:757-768.

38 Nasir O, Umbach AT, Rexhepaj R, Ackermann TF, Bhandaru M, Ebrahim A, Artunc F, Kempe DS, Puchchakayala G, Siraskar B, Foller M, Saeed A, Lang F: Effects of gum arabic (Acacia senegal) on renal function in diabetic mice. Kidney Blood Press Res 2012;35:365-372. 


\section{Kidney \\ Blood Pressure Research}

Feger et al.: CORM-2-induced inhibition of vitamin D3 activation

-39 Pathare G, Foller M, Daryadel A, Mutig K, Bogatikov E, Fajol A, Almilaji A, Michael D, Stange G, Voelkl J, Wagner CA, Bachmann S, Lang F: OSR1-sensitive renal tubular phosphate reabsorption. Kidney Blood Press Res 2012;36:149-161.

-40 Alesutan I, Daryadel A, Mohebbi N, Pelzl L, Leibrock C, Voelkl J, Bourgeois S, Dossena S, Nofziger C, Paulmichl M, Wagner CA, Lang F: Impact of bicarbonate, ammonium chloride, and acetazolamide on hepatic and renal SLC26A4 expression. Cell Physiol Biochem 2011;28:553-558.

-41 Pathare G, Foller M, Michael D, Walker B, Hierlmeier M, Mannheim JG, Pichler BJ, Lang F: Enhanced FGF23 serum concentrations and phosphaturia in gene targeted mice expressing WNK-resistant SPAK. Kidney Blood Press Res 2012;36:355-364.

42 Dermaku-Sopjani M, Sopjani M, Saxena A, Shojaiefard M, Bogatikov E, Alesutan I, Eichenmuller M, Lang F: Downregulation of NaPi-IIa and NaPi-IIb Na-coupled phosphate transporters by coexpression of Klotho. Cell Physiol Biochem 2011;28:251-258.

43 Pelzl L, Pakladok T, Pathare G, Fakhri H, Michael D, Wagner CA, Paulmichl M, Lang F: DoCA sensitive pendrin expression in kidney, heart, lung and thyroid tissues. Cell Physiol Biochem 2012;30:1491-1501.

-44 Voelkl J, Pasham V, Ahmed MS, Walker B, Szteyn K, Kuhl D, Metzler B, Alesutan I, Lang F: Sgk1-dependent stimulation of cardiac $\mathrm{Na}+\mathrm{H}+$ exchanger Nhe1 by dexamethasone. Cell Physiol Biochem 2013;32:25-38.

45 Martin A, David V, Quarles LD: Regulation and function of the FGF23/klotho endocrine pathways. Physiol Rev 2012;92:131-155.

46 Dai B, David V, Alshayeb HM, Showkat A, Gyamlani G, Horst RL, Wall BM, Quarles LD: Assessment of 24,25(OH)2D levels does not support FGF23-mediated catabolism of vitamin D metabolites. Kidney Int 2012;82:1061-1070.

47 Medici D, Razzaque MS, Deluca S, Rector TL, Hou B, Kang K, Goetz R, Mohammadi M, Kuro OM, Olsen BR, Lanske B: FGF-23-Klotho signaling stimulates proliferation and prevents vitamin D-induced apoptosis. J Cell Biol 2008;182:459-465.

-48 Reiter CE, Alayash AI: Effects of carbon monoxide (CO) delivery by a CO donor or hemoglobin on vascular hypoxia inducible factor 1alpha and mitochondrial respiration. FEBS Open Bio 2012;2:113-118.

-49 Choi YK, Kim CK, Lee H, Jeoung D, Ha KS, Kwon YG, Kim KW, Kim YM: Carbon monoxide promotes VEGF expression by increasing HIF-1alpha protein level via two distinct mechanisms, translational activation and stabilization of HIF-1alpha protein. J Biol Chem 2010;285:32116-32125.

50 Farrow EG, Yu XJ, Summers LJ, Davis SI, Fleet JC, Allen MR, Robling AG, Stayrook KR, Jideonwo V, Magers MJ, Garringer HJ, Vidal R, Chan RJ, Goodwin CB, Hui SL, Peacock M, White KE: Iron deficiency drives an autosomal dominant hypophosphatemic rickets (ADHR) phenotype in fibroblast growth factor-23 (Fgf23) knock-in mice. Proc Natl Acad Sci USA 2011;108:E1146-E1155.

-51 Clinkenbeard EL, Farrow EG, Summers LJ, Cass TA, Roberts JL, Bayt CA, Lahm T, Albrecht M, Allen MR, Peacock M, White KE: Neonatal iron deficiency causes abnormal phosphate metabolism by elevating FGF23 in normal and ADHR mice. J Bone Miner Res 2013;10.1002/jbmr.2049

\$52 Forster RE, Jurutka PW, Hsieh JC, Haussler CA, Lowmiller CL, Kaneko I, Haussler MR, Kerr Whitfield G: Vitamin D receptor controls expression of the anti-aging klotho gene in mouse and human renal cells. Biochem Biophys Res Commun 2011;414:557-562.

53 Csongradi E, Juncos LA, Drummond HA, Vera T, Stec DE: Role of carbon monoxide in kidney function: is a little carbon monoxide good for the kidney? Curr Pharm Biotechnol 2012;13:819-826.

-54 Johnson FK, Johnson RA, Durante W, Jackson KE, Stevenson BK, Peyton KJ: Metabolic syndrome increases endogenous carbon monoxide production to promote hypertension and endothelial dysfunction in obese Zucker rats. Am J Physiol Regul Integr Comp Physiol 2006;290:R601-R608.

55 Asai O, Nakatani K, Tanaka T, Sakan H, Imura A, Yoshimoto S, Samejima K, Yamaguchi Y, Matsui M, Akai Y, Konishi N, Iwano M, Nabeshima Y, Saito Y: Decreased renal alpha-Klotho expression in early diabetic nephropathy in humans and mice and its possible role in urinary calcium excretion. Kidney Int 2012;81:539-547.

56 Cheng MF, Chen LJ, Cheng JT: Decrease of Klotho in the kidney of streptozotocin-induced diabetic rats. J Biomed Biotechnol 2010;2010:513853.

57 Zhao Y, Banerjee S, Dey N, LeJeune WS, Sarkar PS, Brobey R, Rosenblatt KP, Tilton RG, Choudhary S: Klotho depletion contributes to increased inflammation in kidney of the $\mathrm{db} / \mathrm{db}$ mouse model of diabetes via RelA (serine)536 phosphorylation. Diabetes 2011;60:1907-1916. 


\section{Kidney \\ Blood Pressure Research}

Feger et al.: CORM-2-induced inhibition of vitamin D3 activation

-58 Teran FJ, Johnson RA, Stevenson BK, Peyton KJ, Jackson KE, Appleton SD, Durante W, Johnson FK: Heme oxygenase-derived carbon monoxide promotes arteriolar endothelial dysfunction and contributes to salt-induced hypertension in Dahl salt-sensitive rats. Am J Physiol Regul Integr Comp Physiol 2005;288:R615-R622.

59 Kuwahara N, Sasaki S, Kobara M, Nakata T, Tatsumi T, Irie H, Narumiya H, Hatta T, Takeda K, Matsubara H, Hushiki S: HMG-CoA reductase inhibition improves anti-aging klotho protein expression and arteriosclerosis in rats with chronic inhibition of nitric oxide synthesis. Int J Cardiol 2008;123:84-90.

60 Carlberg C, Seuter S, Heikkinen S: The first genome-wide view of vitamin D receptor locations and their mechanistic implications. Anticancer Res 2012;32:271-282.

61 Fleet JC, DeSmet M, Johnson R, Li Y: Vitamin D and cancer: a review of molecular mechanisms. Biochem J 2012;441:61-76.

62 Russell MA, Wilson C, Cole PV, Idle M, Feyerabend C: Comparison of increases in carboxyhaemoglobin after smoking "extra-mild" and "non-mild" cigarettes. Lancet 1973;2:687-690.

63 Sen S, Peltz C, Beard J, Zeno B: Recurrent carbon monoxide poisoning from cigarette smoking. Am J Med Sci 2010;340:427-428.

-64 Brot C, Jorgensen NR, Sorensen OH: The influence of smoking on vitamin D status and calcium metabolism. Eur J Clin Nutr 1999;53:920-926.

65 Vervloet MG, van Zuilen AD, Heijboer AC, ter Wee PM, Bots ML, Blankestijn PJ, Wetzels JF: Fibroblast growth factor 23 is associated with proteinuria and smoking in chronic kidney disease: an analysis of the MASTERPLAN cohort. BMC Nephrol 2012;13:20.

66 Goldkorn T, Filosto S: Lung injury and cancer: Mechanistic insights into ceramide and EGFR signaling under cigarette smoke. Am J Respir Cell Mol Biol 2010;43:259-268.

67 Ambrose JA, Barua RS: The pathophysiology of cigarette smoking and cardiovascular disease: an update. J Am Coll Cardiol 2004;43:1731-1737.

68 Rooney C, Sethi T: The epithelial cell and lung cancer: the link between chronic obstructive pulmonary disease and lung cancer. Respiration 2011;81:89-104.

69 Persson LJ, Aanerud M, Hiemstra PS, Hardie JA, Bakke PS, Eagan TM: Chronic obstructive pulmonary disease is associated with low levels of vitamin D. PLoS One 2012;7:e38934.

-70 Cutillas-Marco E, Fuertes-Prosper A, Grant WB, Morales-Suarez-Varela M: Vitamin D deficiency in South Europe: effect of smoking and aging. Photodermatol Photoimmunol Photomed 2012;28:159-161.

71 Deeb KK, Trump DL, Johnson CS: Vitamin D signalling pathways in cancer: potential for anticancer therapeutics. Nat Rev Cancer 2007;7:684-700.

72 Kurosu H, Yamamoto M, Clark JD, Pastor JV, Nandi A, Gurnani P, McGuinness OP, Chikuda H, Yamaguchi M, Kawaguchi H, Shimomura I, Takayama Y, Herz J, Kahn CR, Rosenblatt KP, Kuro-o M: Suppression of aging in mice by the hormone Klotho. Science 2005;309:1829-1833.

73 Liu H, Fergusson MM, Castilho RM, Liu J, Cao L, Chen J, Malide D, Rovira, II, Schimel D, Kuo CJ, Gutkind JS, Hwang PM, Finkel T: Augmented Wnt signaling in a mammalian model of accelerated aging. Science 2007;317:803-806.

74 Doi S, Zou Y, Togao O, Pastor JV, John GB, Wang L, Shiizaki K, Gotschall R, Schiavi S, Yorioka N, Takahashi M, Boothman DA, Kuro-o M: Klotho inhibits transforming growth factor-beta1 (TGF-beta1) signaling and suppresses renal fibrosis and cancer metastasis in mice. J Biol Chem 2011;286:8655-8665.

75 Abramovitz L, Rubinek T, Ligumsky H, Bose S, Barshack I, Avivi C, Kaufman B, Wolf I: KL1 internal repeat mediates klotho tumor suppressor activities and inhibits bFGF and IGF-I signaling in pancreatic cancer. Clin Cancer Res 2011;17:4254-4266.

76 Wolf I, Levanon-Cohen S, Bose S, Ligumsky H, Sredni B, Kanety H, Kuro-o M, Karlan B, Kaufman B, Koeffler HP, Rubinek T: Klotho: a tumor suppressor and a modulator of the IGF-1 and FGF pathways in human breast cancer. Oncogene 2008;27:7094-7105.

-77 Chen B, Ma X, Liu S, Zhao W, Wu J: Inhibition of lung cancer cells growth, motility and induction of apoptosis by Klotho, a novel secreted Wnt antagonist, in a dose-dependent manner. Cancer Biol Ther 2012;13:1221-1228.

78 Usuda J, Ichinose S, Ishizumi T, Ohtani K, Inoue T, Saji H, Kakihana M, Kajiwara N, Uchida O, Nomura M, Ohira T, Ikeda N: Klotho predicts good clinical outcome in patients with limited-disease small cell lung cancer who received surgery. Lung Cancer 2011;74:332-337. 